\title{
Morphoanatomical study, seasonal variation, and larvicidal activity of volatile oils from the leaves of Campomanesia pubescens (DC.) O. Berg (Myrtaceae)
}

\author{
Estudo morfoanatômico, variação sazonal e atividade larvicida dos óleos voláteis das follhas de \\ Campomanesia pubescens (DC.) O. Berg (Myrtaceae) \\ Estudio morfoanatómico, variación estacional y actividad larvicida de aceites volátiles de las hojas \\ de Campomanesia pubescens (DC.) O. Berg (Myrtaceae)
}

Received: 03/01/2021 | Reviewed: 03/08/2021 | Accept: 03/11/2021 | Published: 03/18/2021

\author{
Henrique Margues da Costa \\ ORCID: https://orcid.org/0000-0002-5035-5518 \\ Universidade Federal de Goiás, Brazil \\ E-mail: henriquemarques0611@gmail.com \\ Tatiana de Sousa Fiuza \\ ORCID: https://orcid.org/0000-0003-0135-177X \\ Universidade Federal de Goiás, Brazil \\ E-mail: tatianaanatomia@gmail.com \\ Heleno Dias Ferreira \\ ORCID: https://orcid.org/0000-0001-7763-734X \\ Universidade Federal de Goiás, Brazil \\ E-mail: hdiasicb@gmail.com \\ Fernando Yano Abrao \\ ORCID: https://orcid.org/0000-0002-0553-0946 \\ Universidade Federal de Goiás, Brazil \\ E-mail: yanobruce@gmail.com \\ Camila Aline Romano \\ ORCID: https://orcid.org/0000-0002-3564-6368 \\ Universidade Federal de Goiás, Brazil \\ E-mail: camilaalineromano@gmail.com \\ Leonardo Luiz Borges \\ ORCID: https://orcid.org/0000-0003-2183-3944 \\ Universidade Estadual de Goiás, Brazil \\ Pontifícia Universidade Católica de Goiás, Brazil \\ E-mail: leonardoquimica@gmail.com \\ José Realino de Paula \\ ORCID: https://orcid.org/0000-0002-4424-7692 \\ Universidade Federal de Goiás, Brazil \\ E-mail: pjrpaula@gmail.com
}

\begin{abstract}
The aim of this study was to perform from the morpho-anatomical study, physicochemical characterization, chemical composition, seasonal variability and larvicidal activity of the volatile oils of Campomanesia pubescens (DC.) O. Berg leaves. The botanical material was collected in Hidrolândia, Goiás. Morpho-anatomical characterization and phytochemical screening were performed by conventional methods. Leaf powders were submitted to hydrodistillation in the Clevenger apparatus and the identification of the chemical components of the volatile oils obtained was done by GC-MS. The larvicidal activity was carried out with third-stage larvae of the Aedes aegypti. The leaf blade, the main vein, and the young stem have a uni-stratified epidermis covered by a cuticle. The mesophyll and cortical parenchyma of the main vein and young stem have secretory cavities and idioblasts with crystals. The main rib contains a bicolateral bundle in an open arch. The young stem has a discontinuous band of sclerenchyma external to the phloem cells. Most volatile oil compounds are spathulenol, caryophyllene oxide, $\alpha$-macrocarpene, and z-caryophylleneIn phytochemical analysis, tannins, digitalis, flavonoids, and total phenols were detected. The content of volatile compounds was $7.36 \%$, that of total ash was $1.77 \%$, and that of mucilage was $3.52 \mathrm{ml}$. The volatile oil at the concentration used was inactive against Ae aegypti larvae. The present study contributes to the taxonomic knowledge of the species and provides parameters for quality control of the plant raw material. This work represents the first description of the chemical compounds and seasonal variability of volatile oils from $C$. pubescens leaves collected in Goiás state.
\end{abstract}

Keywords: Plant anatomy; Cerrado; Essential oil; Medicinal plants; Larvicidal activity. 


\begin{abstract}
Resumo
Objetivou-se neste trabalho realizar o estudo morfoanatômico, a caracterização físico-química e determinar a composição química, variabilidade sazonal e larvicida dos óleos essenciais obtido nas folhas de Campomanesia pubescens (DC.) O. Berg. O material botânico foi coletado em Hidrolândia, Goiás. A caracterização morfonanatômica e a triagem fitoquímica foram realizadas por métodos convencionais. Os pós das folhas foram submetidos a hidrodestilação em aparelho de Clevenger e a identificação dos componentes químicos dos óleos voláteis obtidos foi por CG-EM. A atividade larvicida foi realizada com larvas do terceiro estágio do mosquito Aedes aegypti. A lâmina foliar, a nervura principal e o caule jovem apresentam epiderme uniestratificada revestida por cutícula. O mesofilo e o parêquima cortical da nervura principal e caule jovem apresentam cavidades secretoras e idioblastos com cristais. A nervura principal contem feixe bicolateral em arco aberto. O caule jovem, possui uma faixa esclerenquimática descontínua externa ao floema. Os compostos majoritários dos óleos essenciais foram o espatulenol, óxido carifileno, alfa-macrocarpeno e z-cariofileno. Na triagem fitoquímica foram detectados taninos, digitálicos, flavonoides e fenóis totais. O teor de compostos voláteis foi de 7,36\%, o de cinzas totais foi de $1,77 \%$ e o de mucilagem foi de $3,52 \mathrm{ml}$. O oléo volátil na concentração utilizada foi inativo frente às larvas de Ae. aegypti. O presente estudo contribui para o conhecimento taxonômico da espécie e fornece parâmetros de controle de qualidade da matéria-prima vegetal. Esse trabalho representa a primeira descrição dos compostos químicos e variabilidade sazonal dos óleos voláteis das folhas de $C$. pubecens coletadas em Goiás.
\end{abstract}

Palavras-chave: Anatomia vegetal; Cerrado; Óleo essencial; Plantas medicinais; Atividade larvicida.

\title{
Resumen
}

El objetivo del presente trabajo fue realizar el estudio morfoanatómico, la caracterización físico-química y determinar la composición química, variabilidad estacional y larvicida de los aceites esenciales obtenidos en las hojas de Campomanesia pubescens (DC.) O. Berg. El material botánico fue recolectado en Hidrolândia, Goiás, la caracterización morfonanatómica y el cribado fitoquímico se realizaron por métodos convencionales. Los polvos foliares se sometieron a hidrodestilación en aparato Clevenger y la identificación de los componentes químicos de los aceites volátiles obtenidos fue por CG-EM. La actividad larvicida se realizó con larvas del tercer estadio del mosquito Aedes aegypti. El limbo de la hoja, el nervio principal y el tallo joven tienen una epidermis uniestratificada cubierta por cutícula. El mesófilo y el parénquima cortical de la vena principal y el tallo joven tienen cavidades secretoras e idioblastos con cristales. La costilla principal contiene un haz bicolateral en un arco abierto. El tallo joven tiene una banda esclerénquima discontinua externa al floema. Los compuestos principales de los aceites esenciales fueron espatulenol, óxido de carifileno, alfa-macrocarpeno y z-cariofileno. En el cribado fitoquímico se detectaron taninos, digitálicos, flavonoides y fenoles totales. El contenido de compuestos volátiles fue del 7,36\%, el de cenizas totales fue del $1,77 \%$ y el de mucílagos fue de 3,52 ml. El aceite volátil en la concentración utilizada fue inactivo contra las larvas de Ae. aegypti. El presente estudio contribuye al conocimiento taxonómico de la especie y proporciona parámetros para el control de calidad de la materia prima vegetal. Este trabajo representa la primera descripción de los compuestos químicos y la variabilidad estacional de los aceites volátiles de las hojas de C. pubecens recolectadas en Goiás.

Palabras clave: Anatomía vegetal; Cerrado, Aceite esencial; Plantas medicinales; Actividad larvicida.

\section{Introduction}

The Myrtaceae family contains 131 genera and 5,900 species. A total of 23 genera and about 1034 species are distributed in Brazilian regions such as Amazon, Caatinga, Cerrado, Atlantic Forest, Pampa, and Pantanal (Sobral, et al., 2015).

The genus Campomanesia Ruiz and Pav. contains about 80 species (APG IV, 2016). About 31 species are presentes in the Brazilian territory (Sobral, et al., 2015). Five species occur in Goiás state, including Campomanesia adamantium (Cambess.) O. Berg, Campomanesia eugenioides (Cambess.) D. Legrand ex L. R. Landrum, Campomanesia pabstiana Mattos \& D. Legrand, Campomanesia sessiliflora (O. Berg) Mattos Campomanesia pubescens (DC.) O. Berg, (Forzza, 2010). This genus is characterized by 4-18 locular ovary. Inflorescences are dichasium, unifloras, or racemes. The flowers have an open to fully closed chalice, arranged in irregular lobes (Landrum, 1986; Landrum \& Kawasaki 1997).

Campomanesia pubescens (DC.) O. Berg (Myrtaceae) is widely known as "gabiroba" and is a shrub or sub-shrub with 0.5-1.5 m high. Due to its small size, it can be grown in association with other tree fruits, allowing greater production of food by area. Studies show that in the Cerrado in Goiás, the species blooms from September to November (Almeida, et al., 1998). The fruits have a sweet taste and can be consumed in nature or processed in the form of pulps, juices, ice cream, soft drinks, 
sweets, puddings, liqueurs, smoothies or tanned in cachaça (Sano \& Almeida, 1998). C. pubescens are popularly employed to combat diseases of the urinary tract and diarrhea and have an astringent action (Rodrigues \& Carvalho, 2001).

C. pubescens is an aromatic shrub, containing secretory cavities that produce volatile oil. Scientific studies have found ledol and globulol (Cardoso, et al., 2009) to be the major constituents of the volatile oils in the flowers of C. pubecens collected in Mato Grosso do Sul, from the fruits collected in the state of Minas Gerais, limonene, and eucalyptol, in eucalyptus branches, and spatulenol, in the roots bicyclogermacrene, and spatulenol and the leaves, bicyclogermacrene and 1,8 cineol (Chang, et al., 2011).

An in vitro study conducted with extracts and hexane fractions of the fruits of $C$. pubescens, found antimicrobial activity against Staphylococcus aureus, Pseudomonas auruginosa, Escherichia coli, Salmonella setubal, Saccharomyces cerevisiae and Candida albicans (Cardoso et al., 2010). In another investigation by Guerrero, et al. (2010) demonstrated an increase in the number of monocytes in hematological tests in rats after administration of the hydroethanolic extract of $C$. pubescens leaves, suggesting an anti-inflammatory activity. There are no reports in the literature on the seasonal variability of volatile oil compounds or the biological activity of $C$. pubescens on Aedes aegypti larvae, but studies with other species of the Myrtaceae family, such as Eucalyptus, Pepper, Psidium, and Syzygium, have verified larvicidal action (Dias, et al., 2014).

The mosquito Ae aegypti is the vector of human arboviruses, it breeds in standing water (Consoli \& Oliveira, 1994). The main preventive measure is the use of larvicides associated with the elimination of mosquito breeding sites (Zara, et al., 2016). These chemicals can be toxic to humans and other living organisms causing environmental problems (Amer \& Mehlhorn, 2006; Oliveira, et al., 2016). Ecologically sustainable insecticides with lower toxicity and biodegradability are well accepted in this context, volatile oils being an important source (Isman, 2020; Viana, et al., 2018).

Due to the pharmacological potential, this work aimed to carry out the morphoanatomical study of C. pubescens, the quality control of plant raw material (phytochemical screening, content of volatile compounds, total ash, particle size and intumescence index), extract and analyze the chemical constituents of the volatile oils from the leaves, check the monthly variability of volatile oil compounds for a year and their larvicidal activity on third stage larvae of the Aedes aegypti mosquito.

\section{Methodology}

Leaves of C. pubescens from Cerrado region were collected monthly for 12 in Hidrolândia, Goiás, Brazil (786 m altitude, $16^{\circ} 53$ '59” S and $49^{\circ} 13^{\prime}$ ' 29” W). Prof. Dr. José Realino de Paula identified the specimen and a voucher specimen was deposited at the Herbarium of the Federal University of Goiás (n. 67844).

Identification, morphological and phenological descriptions of $C$. pubescens were made with the naked eye, every month for 12 months, in loco, and using the stereoscopic microscope Olympus SZ-ST and specialized bibliographies (Gentry, 1992, Lorenzi, et al., 2003, Martius, 1897).

For the anatomical study, the leaves were fixed in 70\% FPA (formaldehyde, propionic acid, and 70\% ethanol 1: 1: 18 V / V) for 48 hours and preserved in 70\% ethanol. Paradermic sections of the leaf blade (middle third of the inter rib region region) were carried out, cross sections of the leaf blade (leaf margin, middle third of the inter rib region and the main rib); petiole (median region) and young stem branches (second internode internode), stained with Alcian blue/safranin 9: 1 (Kraus \& Arduin, 1997) and Steinmetz (Costa, 2001). Photographic recording of the anatomical structures was performed in a photomicroscope (Zeiss-Axiostar plus) with a coupled digital camera (Canon Power Shot G10) using the Axion Vision 4.8 software.

For analysis of volatile oils, leaves were collected from ten different individuals monthly, oven-dried with air circulation at $40{ }^{\circ} \mathrm{C}$ for 24 hours, triturated immediately before volatile oil extraction. $90 \mathrm{~g}$ of th poder was submitted to hydrodistillation in a Clevenger-type apparatus for $2 \mathrm{~h}$. After drying with anhydrous $\mathrm{Na}_{2} \mathrm{SO}_{4}$, the oils were stored in glass vials 
at a temperature of $-18{ }^{\circ} \mathrm{C}$ until further analysis. Each experiment was performed in triplicate. The composition of the volatile oils from leaves was analyzed using a Shimadzu GC/MS-QP5050A fitted with a fused silica SBP-5 $(30 \mathrm{~m} \times 0.25 \mathrm{~mm}$ I.D.; $0.25 \mu \mathrm{m}$ film thickness) capillary column (composed of 5\% phenylmethyl polysiloxane). The following temperature program was used: the temperature was raised from $60-240{ }^{\circ} \mathrm{C}$ at a rate of $3{ }^{\circ} \mathrm{C} / \mathrm{min}$ and then to $280{ }^{\circ} \mathrm{C}$ at a rate of $10{ }^{\circ} \mathrm{C} / \mathrm{min}$, ending with $10 \mathrm{~min}$ at $280{ }^{\circ} \mathrm{C}$. The carrier gas (helium) had a flow rate of $1 \mathrm{~mL} / \mathrm{min}$, and the split mode had a ratio of 1:20. The injection port was set at $225^{\circ} \mathrm{C}$. The operating parameters for the quadrupole mass spectrometer were as follows: the interface temperature was set to $240{ }^{\circ} \mathrm{C}$ and the electron impact ionization to $70 \mathrm{eV}$, with a scan mass range of $40-350 \mathrm{~m} / \mathrm{z}$ at a sampling rate of $1 \mathrm{scan} / \mathrm{s}$. The components were identified by comparison of the retention indices of the components to those of C9-C28 n-alkanes and comparison of the mass spectra with literature data (Van Den Dool \& Kratz, 1963; Adams, 2007).

Principal component analysis (PCA) was used to evaluate the possible interrelationships between the compounds found in volatile leaf oils collected at different months throughout 1 year using Statistica 7 software (Statsoft Inc., Tulsa). Cluster analysis was applied to study the similarity of the samples based on the distribution of the constituents, and hierarchical grouping was performed according to Ward's minimum variance method (Ward, 1963). Canonical discriminant analysis (DCA) was employed to detect the pattern distribution of samples and to identify the componentes that differed between the groups.

The climatic data in this period were obtained from data from the National Institute of Meteorology (INMET, 2020).

For phytochemical studies, analysis of ash and moisture contents, the leaves were collected, placed in plastic bags, dried in an oven with air circulation at a temperature of $40^{\circ} \mathrm{C}$, and later sprayed in a knife mill.

In phytochemical screening, anthraquinone heterosides (formation of ammonium phenates), coumarins (alkaline hydrolysis and observation in ultra-violet light), steroids and triterpenes (Liebermann-Burchard and Salkowski reactions) were investigated; digitalis heterosides (Liebermann-Burchard, Kedde and Keller-Kiliani reactions); starch (lugol); alkaloids (Mayer, Dragendorff, Bouchardat, Bertrand, Hager reactants, $1 \%$ tannic acid); flavonoid heterosides (Shinoda reaction; oxalicboric; with $\mathrm{H}_{2} \mathrm{SO}_{4}$ concentrate; with alkali hydroxide; aluminum chloride and ferric chloride); saponin heterosides (foam index); tannins (reactions with gelatin, quinine sulfate $1 \%$, copper acetate $4 \%$, ferric chloride $2 \%$ and sodium hydroxide $20 \%$ ) and methylxanthines (murexide reaction) (Costa, 2001; Cunha, 2005).

The determination of the content of volatile compounds was carried out in a moisture analyzer that produces radiation in the infrared region by using a halogen lamp (Ohaus model MB35) (Brazil, 2010). For this, $1 \mathrm{~g}$ of the powdered vegetable drug was weighed, the material was evenly distributed on the scale plate and the bowl was heated to constant weight. After starting the process, the moisture content was shown on the device's digital display in approximately 10 minutes. The experiment was carried out in triplicate, the average, standard deviation, and variation coefficient were calculated.

To determine the swelling index, $1 \mathrm{~g}$ of the powdered drug was weighed and transferred to a $25 \mathrm{ml}$ becker, the volume of the dry drug in the beaker was measured and $25 \mathrm{ml}$ of water was added. The beaker was capped with a ground cover and stirred every 10 minutes for 1 hour. After stirring, the mixture was left to stand for 3 hours at room temperature. In the end, the volume of plant material plus mucilage was measured. The experiment was carried out in triplicate.

3 crucibles were calcined at $500^{\circ} \mathrm{C}$ for 60 minutes to determine the total ash content. of the pulverized vegetable drug $(3 \mathrm{~g})$ was weighed and transferred to the calcined and tared crucible. The sample was incinerated by gradually increasing the temperature: 30 minutes at $200{ }^{\circ} \mathrm{C}, 60$ minutes at $400{ }^{\circ} \mathrm{C}$, and 90 minutes at $600^{\circ} \mathrm{C}$. It was cooled in a desiccator and weighed. The experiment was carried out in triplicate.

To evaluate the larvicidal activity, the volatile oil from C. pubecens leaves collected in April 2020 were prepared in serial dilutions 100-20 $\mu \mathrm{g} / \mathrm{ml}$. Twenty-third-instar Ae. aegypti larvae were exposed to $25 \mathrm{~mL}$ of the test solution and mortality events were quantified after 24 hours. All assays were performed in triplicate in a biological chamber with a temperature of 25 
${ }^{\circ} \mathrm{C} \pm 1{ }^{\circ} \mathrm{C}$, relative humidity $85 \% \pm 5 \%$, and photoperiod of $12 \mathrm{~h}$ (Silva, et al., 2003; WHO, 2005). Water and surfactant were negative controls and the positive control used was the temephos $0,012 \mu \mathrm{g} / \mathrm{mL}$. The results were analyzed using non-linear statistics (PROBIT), Statistica 12.0. The following criteria were used to assess larvicidal activity: lethal concentration 50 (LC50) $\leq 50 \mu \mathrm{g} / \mathrm{mL}$ is considered very active, LC50 between 50 and $100 \mu \mathrm{g} / \mathrm{mL}$ active, and LC50 $>100 \mu \mathrm{g} / \mathrm{mL}$ inactive (Silvério, et al., 2020).

\section{Results}

\subsection{Morphological study}

C. pubescens (Figure $1 \mathrm{~A}$ and B) occurs in open Cerrado stony and sandy soil. Flowering occurs from September to October and fruiting from October to November.

Figure 1. Campomanesia pubescens. A - General aspect of the plant. B- Detail of flowers.

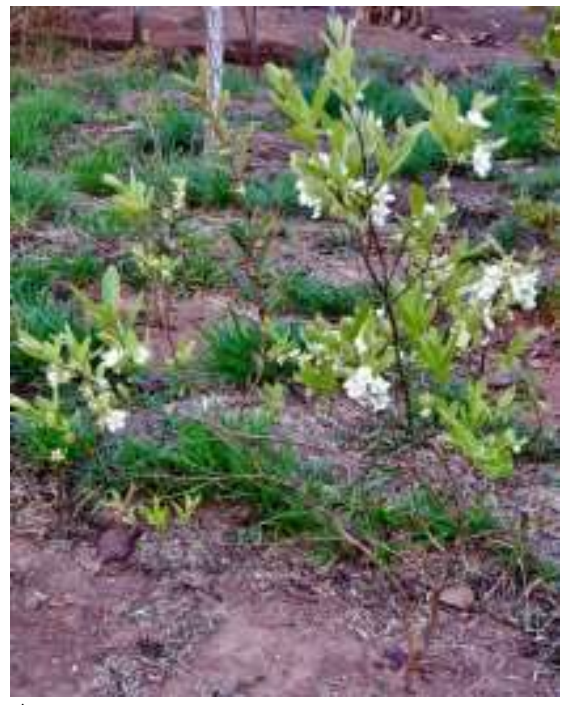

A

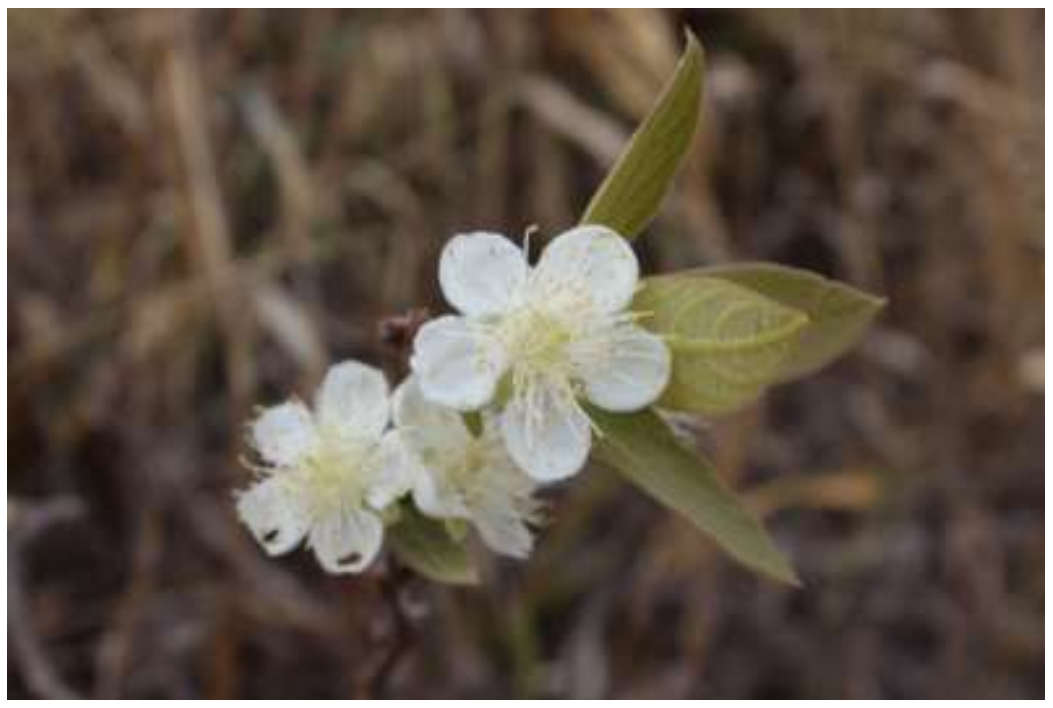

$\mathbf{B}$

Source: Authors.

It is a woody shrub, about $1.5 \mathrm{~m}$ tall in clump. Green and medium leaves, discolors (the adaxial face of the leaves has a darker tone compared to the abaxial face), full of trichomes on both sides, simple, crossed, and petiolate opposite. The leaf blade is elliptical, $5-7 \mathrm{~cm} \times 1.5-2 \mathrm{~cm}$ with obtuse apex, obtuse base, entire margin, peninervous venation.

The flowers are androgynous, heteroclamidous, white, pedunculated, caryophyllus corolla with 5-petals, dialipetals and actinomorphic, androceu polistémone, of simple, free and white fillet. Spherical berry type fruit, becoming yellow when ripe.

\subsection{Anatomic study}

The leaf of $C$. pubescens, in cross section, shows uni-stratified epidermis with rectangular cells covered by cuticle, thick in the adaxial portion and thin in the abaxial portion. The epidermal cells of the adaxial face are more elongated vertically (Figure 2A - arrowhead) than those of the abaxial face (Figure 2A - thick arrow). Presence of non-branched, single-celled trichomes with the absence of a pedal cell (Figure 2A - thin arrow) on both sides of the leaf blade. Anomocytic stomata were found on the abaxial face (Figure 2B). 
The mesophyll, in the transverse section, is dorsiventral, the palisade parenchyma has up to 3 layers of cells, and the lacunous parenchyma of 4 to 6 layers of cells, composed of cells of different shapes (Figure 2C). In the mesophyll, the presence of idioblasts with polyhedral crystals (Figure 2C) or druses and secretory cavities (Figure 2D) was observed. The leaf margin, in the cross-section, is rounded and covered by a cuticle.

Figure 2. A-C-D- Cross-section of the inter-rib from C. pubescens leaves (Alcian blue/safranin). B - Paradermal section of the leaf blade showing anomocytic stomata (Steimntz). Tr - Trichomes. Ep - Epidermis. Es - Stomata. CP - Polyhedral crystal. Ca - Secretory cavity.

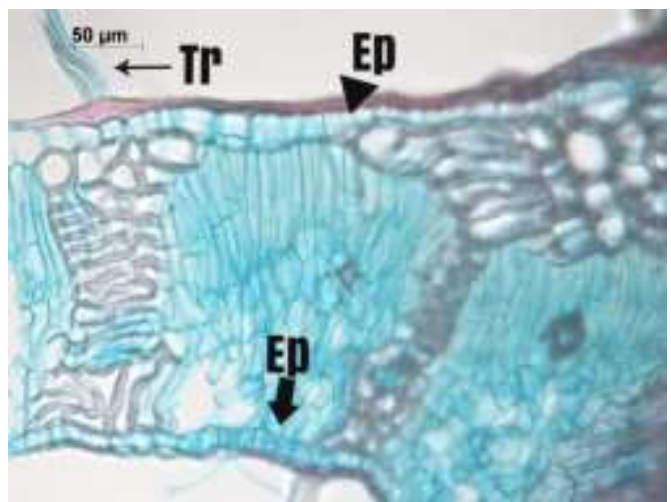

A

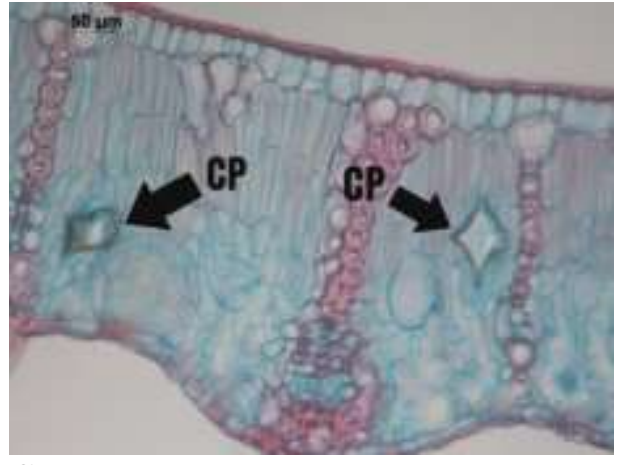

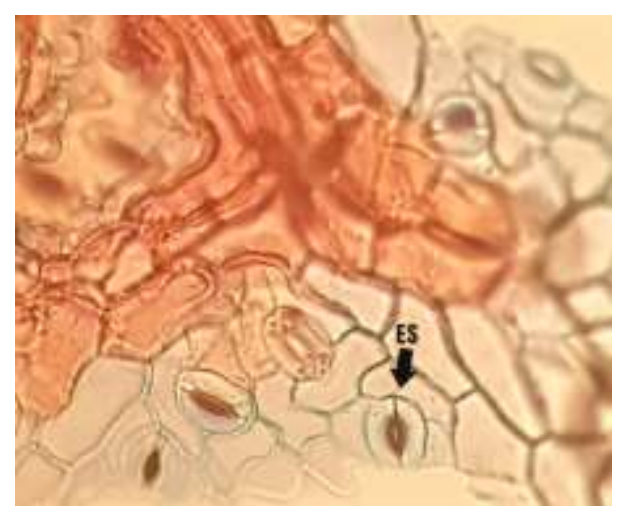

B

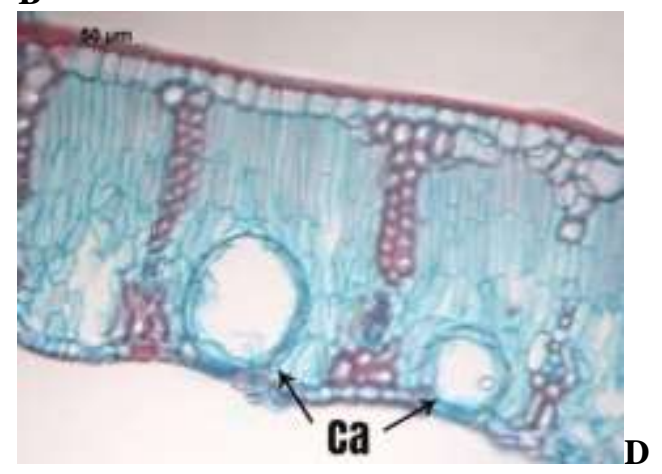

Source: Authors.

The midrib, in the cross-section, has a plane-convex to slightly biconvex outline (Figure $3 \mathrm{~A}$ ). The collenchyma, just below the epidermis, has 2-3 layers of cells, the cortical parenchyma has 5 to 8 layers of cells (Figure 3B), with the presence of idioblasts containing polyhedral crystals (Figure 3C) or druses and secretory cavities dispersed in the cortical parenchyma. The vascular bundle is bicollateral with an open arch shape. A sclerenchyma band that emits projections up to the xylem surrounds the external phloem. The internal phloem has sclerenchyma cells dividing it into small sets of phloem cells. 
Figure 3. A, B, C - Cross-sections of the midrib from C. pubescens leaves. A- Overview. B- Detail of the cortical parenchyma and vascular bundle: sclerenchyma band, phloem and xylem. CP - Polyhedral crystal. CD - Druze-shaped crystal. Ca Secretory cavity. ES - Sclerenchyma.

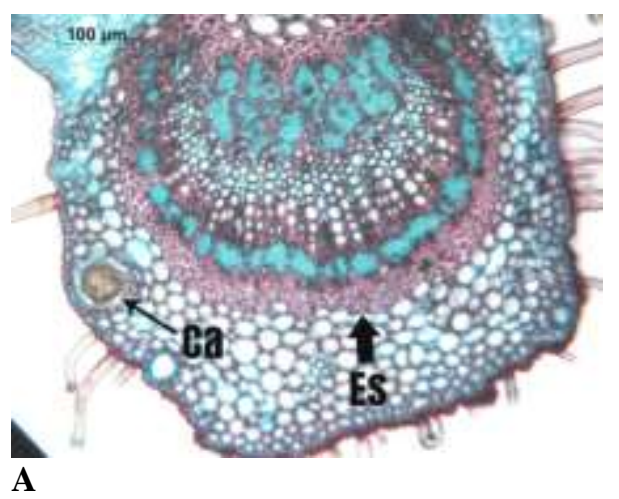

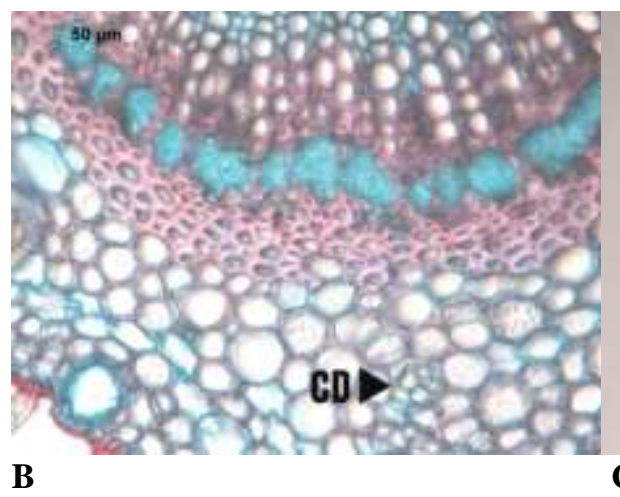

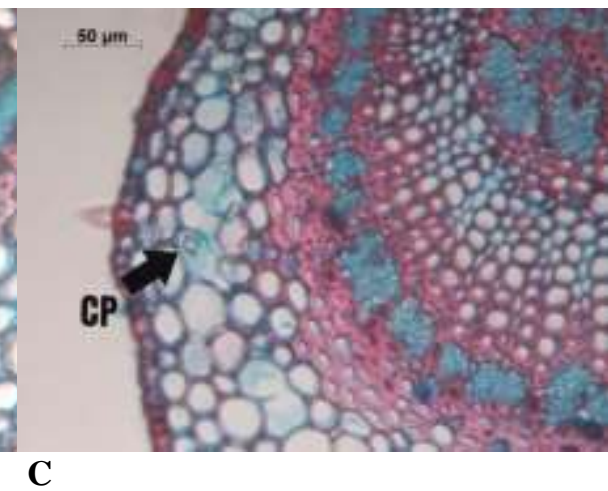

Source: Authors.

The petiole, in the transverse section, has a plane-convex outline, delimited by an epidermal layer covered by a thick cuticle. It presents single-celled trichomes (Figure 4A). The cortical parenchyma has 10 to 12 layers of cells, with the occurrence of idioblasts containing druse-type crystals (Figure 4B - arrowhead) or polyhedral crystals (Figure 4C - thick arrow) and secretory cavities (Figure 4D - thin arrow). The vascular bundle is bicollateral in the shape of an open arch and is surround by a 1 to 3 layers strip of sclerenchymatous cells.

Figure 4. A, B, C, D, E - Cross-sections of the petiole of $C$. pubescens leaves. A- Overview. B- Detail of the cortical parenchyma with druze-shaped crystal. C- Detail of the Polyhedral crystal. D- Secretory cavity in the cortical parenchyma and overview of the vascular bundle. CD - Druze-shaped crystal. CP - Polyhedral crystal. Ca - Secretory cavity. (Alcian blue/safranin).

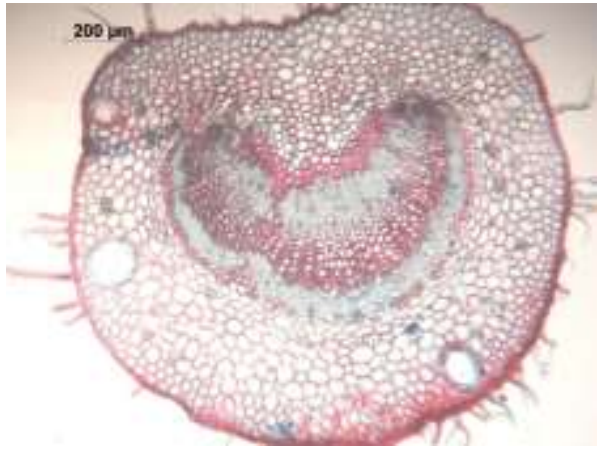

A

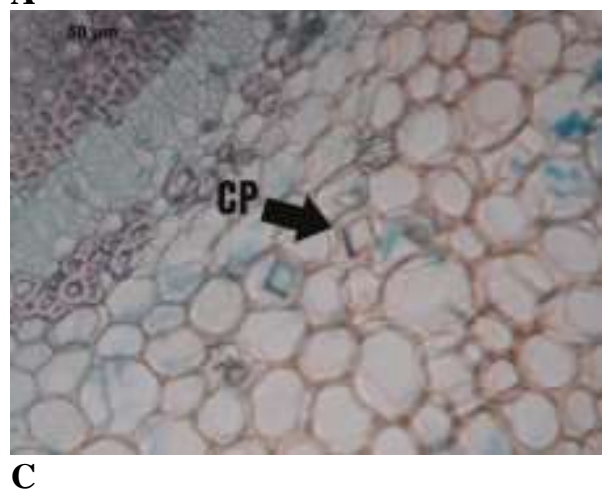

C

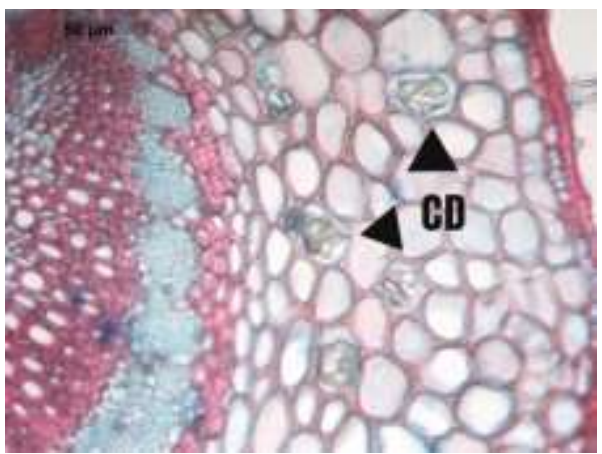

$\mathbf{B}$

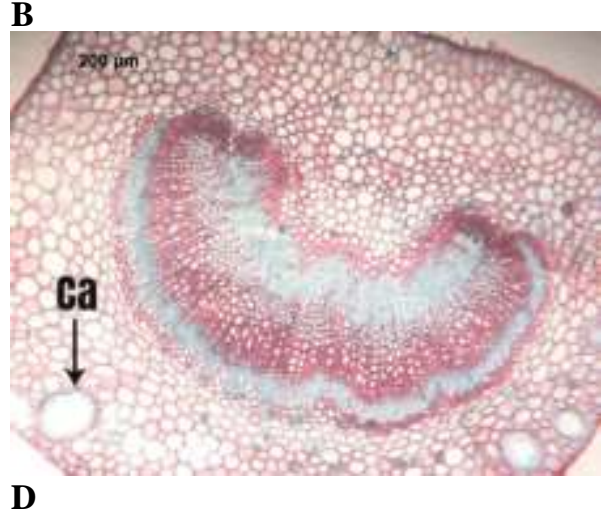

Source: Authors. 
The young stem, in cross-section, with a cylindrical shape (Figure 5A), is delimited by a uni-stratified epidermis and covered by a thick cuticle (Figure 5B) and there are unicellular non-branched trichomes. The cortical parenchyma contains up to 10 layers of cells, presenting idioblasts with druses (Figure 5C - arrowhead) or polyhedral crystals (Figure 5C - thick arrow) and secretory cavity (Figure 5B). A discontinuous sclerenchyma band, separated by parenchymal cells, externally to the phloem (Figure 5D) are observed. In the medullary parenchyma, there is the presence of scattered sclerenchyma cells

Figure 5. Cross-section of $C$. pubescens young stem. A- Overview. B- Detail of the secretory cavity in the cortical parenchyma. C- Detail of the druze-shaped crystal and polyhedral crystal. D- vascular bundle detail. CD- Druze-shaped crystal. CP - Polyhedral crystal. Ep - Epidermis. Fe - Sclerenchymatic band. (Alcian blue/safranin).

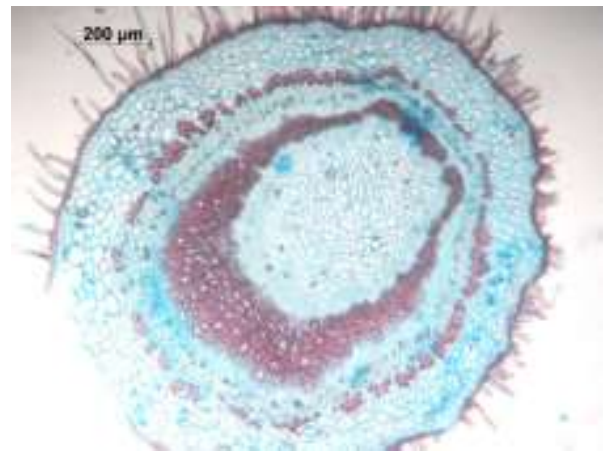

A

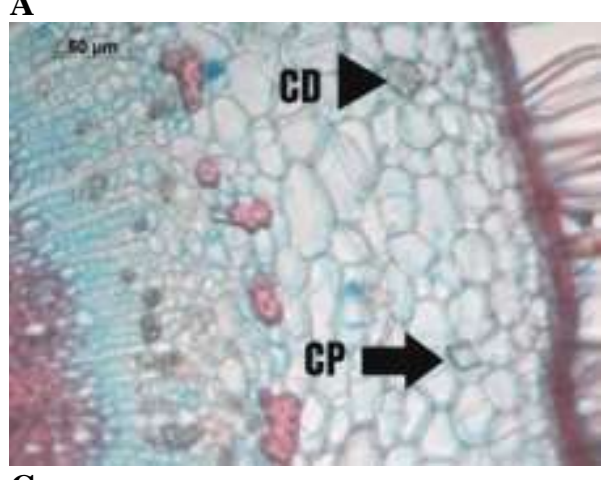

C

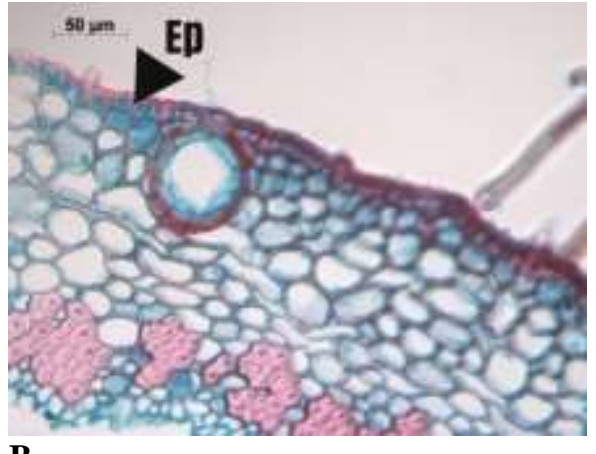

B

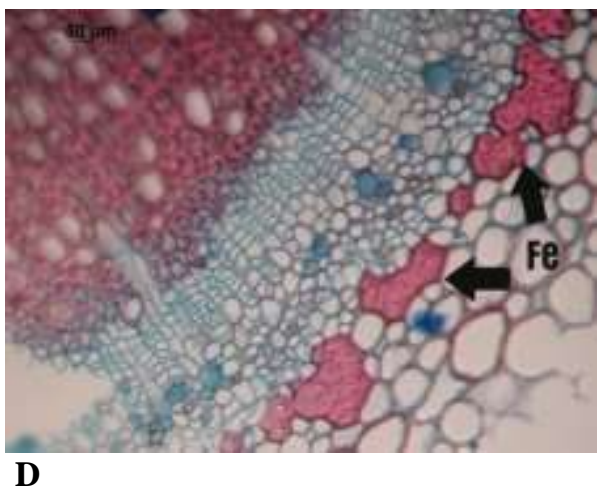

Source: Authors.

\subsection{Volatile oil}

During the leaf collection period, the months of greatest rainfall were October / 2018 (148.6 mm), November / 2018 (181.6 mm), December / 2018 (184.6 mm), February / 2019 (223.4 mm), March / 2019 (134.6 mm), April / 2019 (265.0 mm), and the temperature ranged from 17.2 to 36.7 o C. The months with the lowest rainfall were June / 2019 (0.0 mm), July / 2018 (0.0 mm), August / 2018 (34.4 mm), September / 2018 (38.0 mm), January / 2019 (62.3 mm) and May / 2019 (44.4 mm) and the temperature ranged from 8.6 to $37.4^{\circ} \mathrm{C}$ (Table 1$)$. 
Table 1. Climatic analysis during the period of leaf collection of $C$. pubescens. Source: INMET (Goiânia Station - OMM: 83423), 2020.

\begin{tabular}{cccccc}
\hline Station & Date & Rainfall total & $\begin{array}{c}\text { Maximum } \\
\text { temperature }\left({ }^{\circ} \mathbf{C}\right)\end{array}$ & $\begin{array}{c}\text { Temperature } \\
\text { minimum }\left({ }^{\circ} \mathbf{C}\right)\end{array}$ & $\begin{array}{c}\text { Moisture } \\
\text { Relative }\end{array}$ \\
\hline 83423 & $07 / 31 / 2018$ & 0 & 33.1 & 10.9 & 53.4 \\
83423 & $08 / 31 / 2018$ & 18.8 & 34.4 & 8.6 & 48.4 \\
83423 & $09 / 30 / 2018$ & 38.0 & 37.4 & 11.3 & 46.7 \\
83423 & $10 / 31 / 2018$ & 148.6 & 36.7 & 18.5 & 67.5 \\
83423 & $11 / 30 / 2018$ & 181.6 & 32.9 & 18.5 & 75.8 \\
83423 & $12 / 31 / 2018$ & 184.6 & 35.3 & 17.6 & 69.2 \\
83423 & $01 / 31 / 2019$ & 63.2 & 35.3 & 17.3 & 65.9 \\
83423 & $02 / 28 / 2019$ & 223.4 & 35.9 & 18.0 & 73.6 \\
83423 & $03 / 31 / 2019$ & 134.6 & 33.9 & 17.8 & 73.9 \\
83423 & $04 / 30 / 2019$ & 265.0 & 32.6 & 17.2 & 74.7 \\
83423 & $05 / 31 / 2019$ & 44.4 & 32.7 & 13.0 & 70.8 \\
83423 & $06 / 30 / 2019$ & 0 & 32.5 & 11.9 & 61.0 \\
\hline
\end{tabular}

Source: Authors.

The yield of volatile oils ranged from 0.07 to $0.18 \%$. The presence of oxygenated monoterpenes $(0.1-0.6 \%)$, sesquiterpene hydrocarbons (8.4-79.9\%), and oxygenated sesquiterpenes (17.0-86.0\%) was found. The major compounds in volatile oils were spatulenol (ranging from 1.3 to $43.4 \%$ ), caryophyllene oxide (ranging from 1.3 to 29.7\%), $\alpha$-macrocarpene (ranging from 2.2 to 22.4\%), and z- caryophyllene (ranging from 1.8 to 19.5\%) (Table 2).

Table 2. Percentage of volatile oil chemical compounds from C. pubescens leaves collected in Hidrolândia, Goiás.

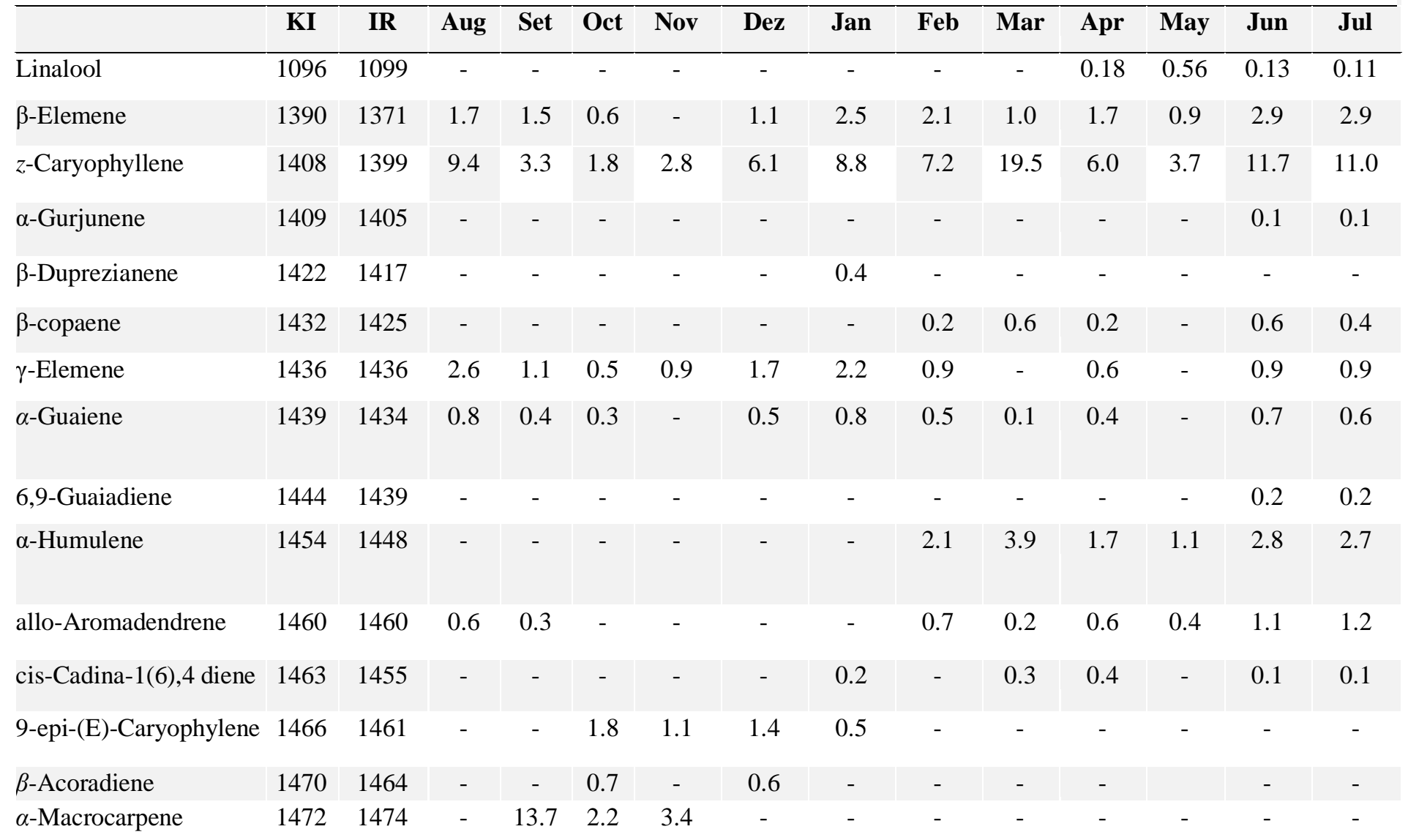




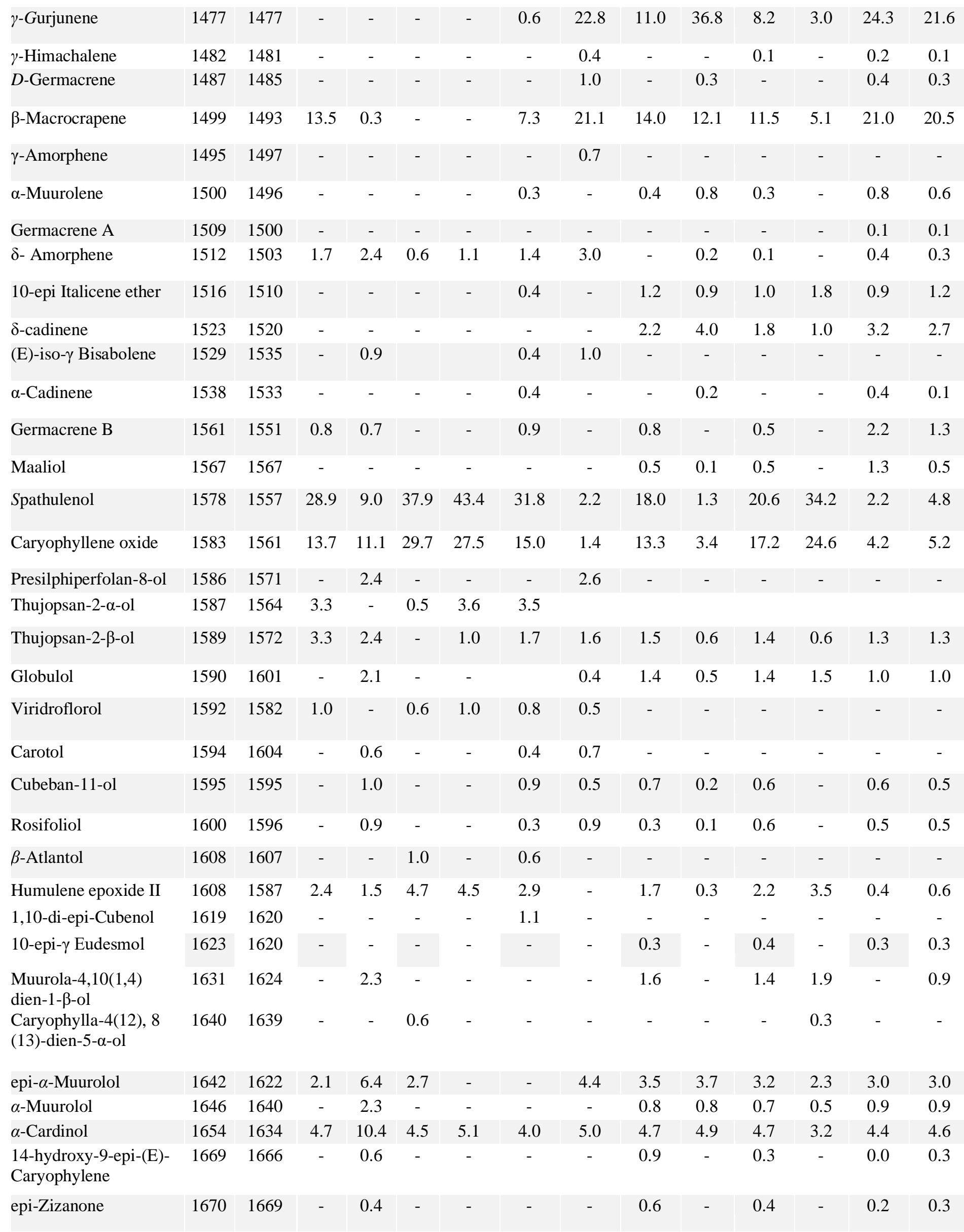




\begin{tabular}{|c|c|c|c|c|c|c|c|c|c|c|c|c|c|c|}
\hline Mustakone & 1676 & 1653 & - & 0.3 & 2.9 & - & - & - & 0.3 & - & 0.7 & 1.3 & - & 0.1 \\
\hline Khusinol & 1680 & 1678 & - & 0.4 & - & - & - & - & - & - & - & - & 0.3 & 0.2 \\
\hline $\begin{array}{l}\text { Germacra- } \\
4(15), 5,10(14) \text {-trien-1- } \\
\alpha \text {-ol }\end{array}$ & 1686 & 1680 & - & 0.6 & - & - & - & - & - & - & 0.3 & - & - & 0.1 \\
\hline Shyobunol & 1688 & 1684 & - & 0.4 & - & - & - & 0.2 & - & 0.2 & 0.3 & - & 0.2 & 0.3 \\
\hline $\begin{array}{l}\begin{array}{l}\text { Oxygenated } \\
\text { monoterpenes }\end{array} \\
\end{array}$ & & & 0.0 & 0.0 & 0.0 & 0.0 & 0.0 & 0.0 & 0.0 & 0.0 & 0.2 & 0.6 & 0.1 & 0.1 \\
\hline Sesquiterpenes & - & - & 31.1 & 24.6 & 8.4 & 9.4 & 22.6 & 65.4 & 42.1 & 79.9 & 34.1 & 15.2 & 74.1 & 67.5 \\
\hline $\begin{array}{l}\begin{array}{l}\text { Oxygenated } \\
\text { sesquiterpenes }\end{array} \\
\end{array}$ & - & & 59.4 & 55.0 & 85.1 & 86.0 & 63.4 & 20.3 & 51.3 & 17.0 & 58.0 & 75.6 & 21.6 & 26.4 \\
\hline Total identified (\%) & - & - & 90.4 & 79.6 & 93.5 & 95.3 & 86.0 & 85.7 & 93.4 & 96.8 & 92.3 & 91.3 & 95.8 & 94.0 \\
\hline Yield (\%) & - & - & 0.07 & 0.06 & 0.13 & 0.12 & 0.11 & 0.09 & 0.1 & 0.1 & 0.12 & 0.1 & 0.18 & 0.18 \\
\hline
\end{tabular}

Source: Authors.

The results obtained from PCA and the cluster analysis showed the existence of chemical variability among volatile oils obtained from $C$. pubecens leaves (Figure 6). Figure 7 indicates that the relative position of the 2D axis originated in the PCA. This analysis suggests that cluster I (volatile leaf oils collected in (February, April, May, August, and December) is characterized by the compound $\alpha$-cadinol and $\alpha$-macrocarpene. Cluster II (volatile oils from leaves collected in September, October, and November) is characterized by caryophyllene oxide and 9-epi (E) - caryophyllene. In addition, cluster III (leaves collected in January, March, June, July) contains $\gamma$-gurjunene, z- caryophyllene, $\delta$-cadinene, and $\beta$-macrocarpene. The results indicate that the classification proposed by the PCA and HCA was adequate for the classification of the samples regarding the chemical profile of volatile oils.

Figure 6. Similarity dendrogram based on Euclidean distance concerning the leaf collection period of $C$. pubescens. From the PCA analysis, it was possible to form three clusters concerning the compounds present in volatile oils.

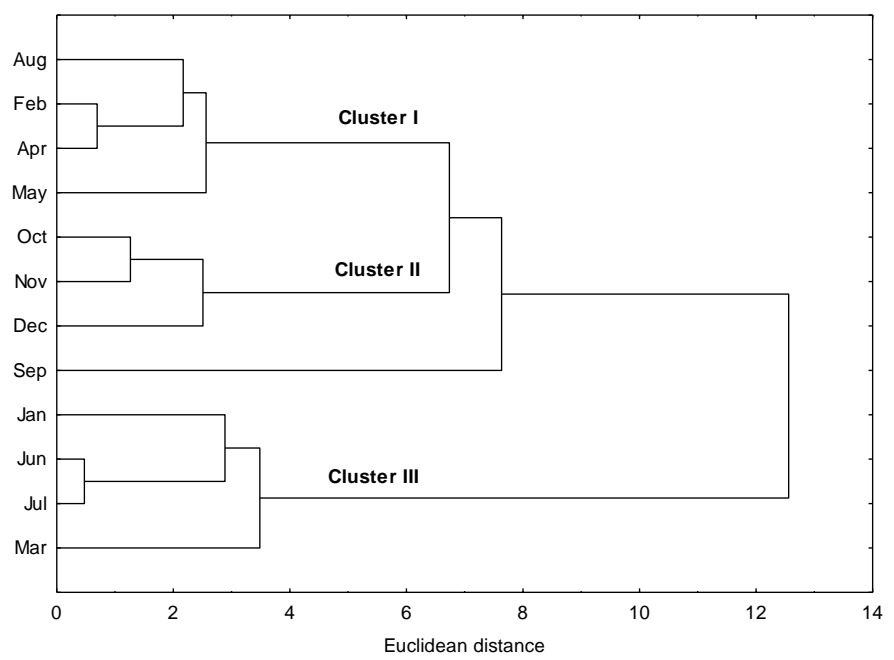

Source: Authors. 
Figure 7. Scatterplot of PCA of the essential oils from the leaves of C. pubescens samples collected from Hidrolândia. a Axes referring to the scores of samples. B Axes referring to scores of volatile chemicals whose discriminant constituents are represented by vectors.

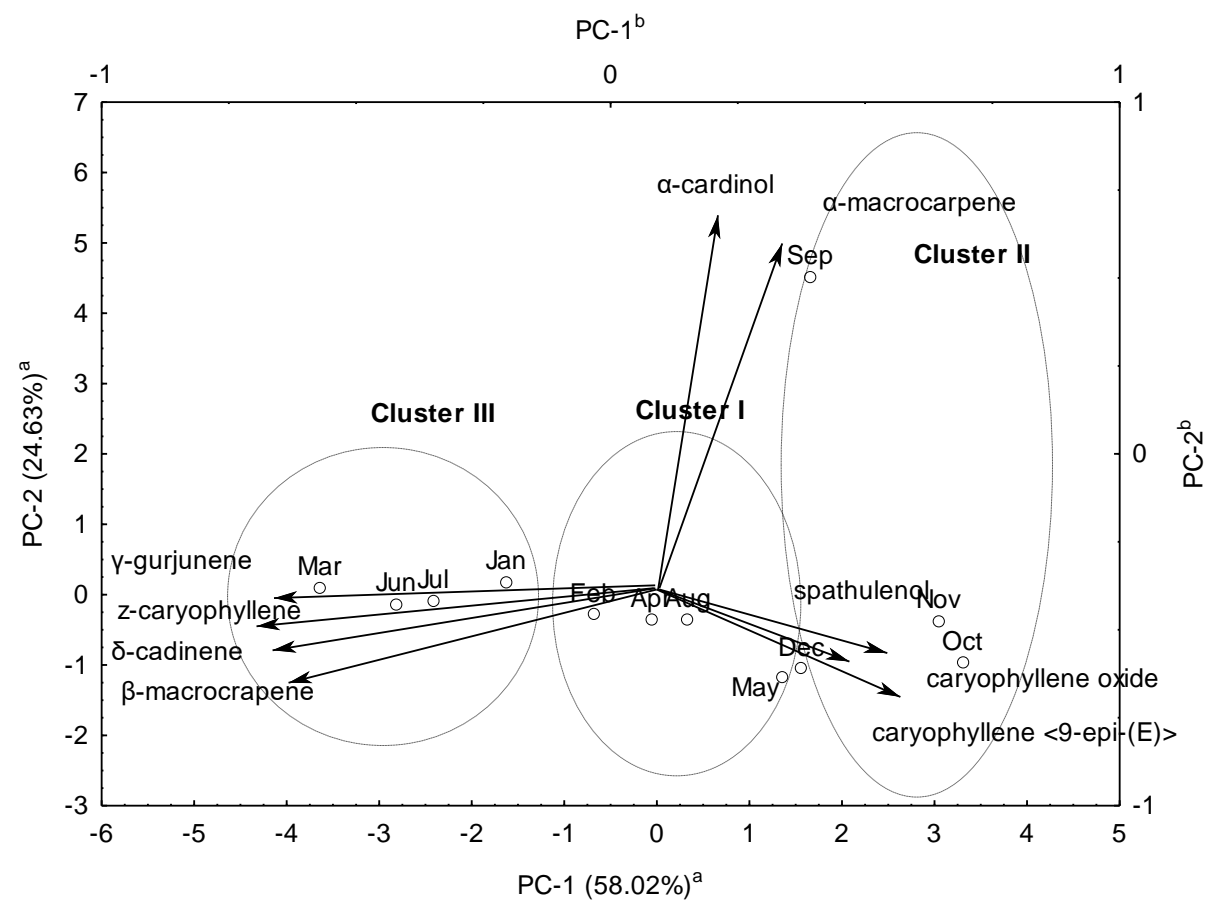

Source: Authors.

The canonical discriminant analysis was performed to assist in the validation of the classification proposed by the hierarchical cluster analysis $(p=0.012)$. The compounds selected to obtain the canonical discriminant analysis model were $\mathrm{z}$ caryophyllene and $\gamma$-gurjunene. The level of correct classification indicated by the analysis of main components was $91.6 \%$. (Brazil 2010), granulometry between $90 \mu \mathrm{m}$ to $450 \mu \mathrm{m}$, with retention of $77.50 \%$ and $10.83 \%$ in the diameters of $450 \mu \mathrm{m}$ (sieve 710 ) and $224 \mu \mathrm{m}$ (sieve 355 ), respectively.

\subsection{Phytochemical Analysis}

In phytochemical screening, the presence of tannins, digitalis heterosides, flavonoids ( $0.84 \%$ content), saponins (foam index less than 100) and total phenols (1.42\% content) were found. The content of volatile compounds was $7.36 \% \pm 1.03$ and a variation coefficient of $14.07 \%$. The total ash content was $1.77 \% \pm 0.0004$. The mucilage content was $3.52 \mathrm{ml}$.

The powder of the leaves of $C$. pubescens presented, according to the Brazilian Pharmacopoeia

\subsection{Determination of lethal concentration in Aedes aegypti larves}

The volatile oil of $C$. pubescens does not induce death in the larvae in twenty-four hours in any of the evaluated dilutions $(100,80,60,40$, and $20 \mu \mathrm{g} / \mathrm{mL})$.

\section{Discussion}

Campomanesia pubescens was observed with flowers from September to October and fruiting from October to November, which is in agreement with Silva, et al. (2009) who observed the peak of flowering and fruiting in September and October, respectively, of $C$. pubescens present in the south of Minas Gerais state. Another study conducted in Mato Grosso do 
Sul, showed that $C$. adamantium follows the same flowering and fruiting periods (Nucci \& Alves-Junior, 2017). According to Fidalgo and Kleinert (2009), the flowering period of Myrtaceae starts in the transition period to wet weather, justifying the peak of flowering in September, followed by fruiting.

According to Lima, et al. (2011a), C. pubescens occurring in the state of Paraná, is a shrub or sub-shrub, ranging from $0.5 \mathrm{~m}-1.5 \mathrm{~m}$, with discolored, petiolate green leaves, densely covered by trichomes, elliptical and lanceolate leaf blade, cuminated apex or acute and acute base, entire margin. The flowers have glabrous petals or with trichomes only on the margins, polystemone (100 to 160 stamens), ovary $5-8$ locular. The fruits are yellowish, globose, and smooth. The present work differs only in the classification of the apex and the base, presenting them as obtuse. According Amaral, et al. (2016) characteristics that proved the identification of the species $C$. pubescens are associated with the presence of pubescence or puberulence; bracts in the shape of scales or tiny leaves; sepals acute, rounded or intermediate forms; green or yellow-green fruits and ovary with 4 to 7 locules.These being the ones observed in this work. Oliveira, et al. (2018) observed morphological features of Campomanesia adamantium (Cambess.) O.Berg, C. eugenioides var. eugenioides (Cambess.) D.Legrand ex Landrum, C. eugenioides var. desertorum (DC.) Landrum, C. xanthocarpa var. xanthocarpa (Mart.) O.Berg and $C$. xanthocarpa var. littoralis (D.Legrand) some characteristics similar to those found in this study, such as being predominat shrub, with leaves petiolate and opposite.

C. pubescens is similar to $C$. adamantium, differentiating itself by conspicuous indument, besides, the corded leaf base does not occur in C. pubescens (Landrum, 1986). Another method of characterizing C. pubescens within the genus Campomanesia is that the leaves are strongly discolored, both fresh and dry in herbaceous materials (Lima, et al., 2011a).

A thick cuticle in the adaxial face, and a thin cuticle in the abaxial face, cover the $C$. pubescens leaves. The cuticle is an adaptation to the Cerrado environment and acts as a protective layer against the loss of water to the environment and in the protection against excess brightness (Appezzato-da-Glória \& Carmello-Guerreiro, 2009). In C. pubescens, the presence of unicellular trichomes was observed, with the absence of a pedal cell, corroborating with Conti, et al. (1997) who described these characteristics as a synapomorphy of Myrtaceae.

The dorsiventral mesophyll presented in the leaves of $C$. pubescens can be described as another evolutionary aspect, that due to the shape and arrangement of the palisade cells, the chloroplasts can be located parallel to the cell walls, intensifying photosynthesis (Appezzato-da-Glória \& Carmello-Guerreiro, 2009).

Gomes, et al. (2009), in their study, anatomically analyzed leaves of four species of the family Myrtaceae (Campomanesia adamantium (Cambess.) O. Berg, Myrcia cordifolia O. Berg, M. decrescens O. Berg and M. torta DC) and observed that all are hypoestomatic, as in the present study for $C$. pubescens. However, in C. adamantium they found anomocytic and paracitic stomata, while in $C$. pubescens they were observed only anomocytic stomata, which can be used as a characteristic for differentiation.

The presence of secretory cavities in different parts of Myrtaceae is widely cited in the literature as a characteristic of the family (Carr \& Carr, 1970). The interior of these cavities may consist of oils, phenols, and mucilages for some species (Fahn, 1979). Kuster and Vale (2016) observed that in the leaf secretory cavities are presents among the mesophyll cells. Histochemical tests demonstraeded voltile oils widely distributed in the secretory cavities of $C$. adamantium, as presented in this study, observing the presence of secretory cavities in the mesophile, in the cortical parenchyma of the main vein, petiole, and young stem. Idioblasts containing polyhedral crystals or druses were also found in the various organs of C. pubescens, differentiating from C. adamantium which, according to Gomes, et al. (2009) contain only polyhedral crystals. Oliveira, et al. (2018) described secretory cavities distributed on leaves of others species of Campomanesia, parenchymatous cells in the leaf blade endings and the mesophyll, always near the epidermis, forming a space delimited by radially disposed cells. The dorsiventral mesophyll and a uni-stratified epidermis on both leaf blade surfaces was observed. The stomata occupied the same 
plane as the epidermal cells. Petiole shapes varied among different morphotypes, with the most common types being planarconvex and concave. It was observed unicellular tector trichomes and bicollateral vascular bundles.

Myrtaceae species may present the midrib biconvex, plane-convex or concave-convex, usually a single bundle in the shape of an almost flat or semi-closed arch (Gomes, et al., 2009), in agreement with what was observed in C. pubescens in this work, presenting the main vein plane-convex, single bundle in the shape of a flat arc.

The results of the morphoanatomic study of $C$. pubescens, corroborate providing basic knowledge, differentiation characteristics and are of great importance to provide standards of control of the vegetable drug if it is used as herbal medicine.

Several chemical constituents were detected in the volatile oil of $C$. pubescens, the majority of which are spatulenol, caryophyllene oxide, $\alpha$-macrocarpene, and z- caryophyllene. Essential oils act in the protection and development of the plant, being able to attract pollinators, reduce the attack of insects by repelling them by insecticidal action, allelopathy, thus acting in the perpetuation of the species (Castro \& Machado, 2003). Cardoso, et al. (2009) obtained ledol (19.8\%), globulol (9.2\%), $\alpha$ cadinol (7.3\%) as volatile oil from the flowers of $C$. pubescens collected in Campo Grande, Mato Grosso do Sul, Brazil, and epi- $\alpha$-muurolol (5.0\%). In the volatile oil from $C$. pubescens leaves, Silva, et al. (2009) found limonene (22.4\%), $\alpha$-pinene (13.3\%), sabinene (9.5\%), bicyclogermacrene (4.4\%), and linalool (3.9\%) as main constituents. Chang et al. (2011) observed as major constituents in the volatile oils from C. pubescens leaves collected in Uberlândia, Minas Gerais, Brazil, bicyclogermacrene (12.54\%), germacrene-D (9.38\%), eucalyptol $(8.17 \%)$, and trans-sabinene hydrate $(5.22 \%)$, in fruits limonene (25.98\%), eucalyptol (24.57\%), $\alpha$-pinene (7.71\%) and $\alpha$-terpineol (6.92\%), in the branches, eucalyptol (24.54\%), spatulenol (8.36\%), bicyclogermacrene D (7.59\%) and germacrene D (5.07\%) predominated and in the roots, bicyclogermacrene (14.65\%), spatulenol (10.23\%), germacrene D (9.02\%) and viridiflorol (7.45\%) were obtained.

The chemical composition of the volatile oil of $C$. pubescens showed a variety of components, due to ongoing studies in different regions, with different temperatures, rainfall, altitudes, soil type, and incidence of ultraviolet rays (Gobbo-Neto \& Lopes, 2007). According to Sangwan, et al. (2001), the production of volatile oils depends on physiological, biochemical, metabolic and genetic aspects of the plant, and may undergo environmental and molecular modulations that elucidate the chemical variations of volatile oils.

The seasonal analysis of the volatile oil of $C$. pubescens, during twelve months, it was possible to observe the formation of three groups (Clusters), associated with flowering/fruiting periods (Cluster II) and vegetative period (Clusters I and II). This study was the first to observe the seasonality of volatile compounds in the oils of this species. Since this plant is a shrub, it is much more susceptible to environmental variations, thus reflecting in the variation of secondary metabolites, thus making it difficult to observe a clear correlation pattern.

C. pubescens is widely used in some regions of Brazil as a medicinal plant, it is necessary to have a better knowledge about the secondary metabolites of the plant, which in most cases have observed pharmacological actions. In this work, tannins were detected in the leaves of $C$. pubescens, confirming the study of Metcalfe and Chalk (1950) when they observed that the species of the Myrtaceae family present tannins that protect the plant against possible attacks by microorganisms and insects (Schmid, 1972).

Abe, et al. (2014) when performing phytochemical prospecting of Campomanesia xanthocarpa Mart. ex O. Berg identified the presence of flavonoid, tannins and saponins, which were also found in the present study. However, the flavonoid content is lower. The presence of tannins and main flavonoids confers antioxidant activity in the human body, with possible effects on the prevention of cardiovascular and circulatory diseases (Ness \& Powles, 1997; Stoclet, et al., 2004) and cancer (Wang \& Mazza, 2002; Katsube, et al., 2003).

Excess water content in vegetable raw materials promotes the development of microorganisms, insects, and unwanted hydrolysis chemical reactions. The humidity index is related to the quality control and preservation of the drug. In the present 
work, the content of volatile compounds was $7.36 \%$ close to the moisture limits for vegetable raw materials established by the Brazilian Pharmacopoeia IV (Brazil, 1988).

Another important method for the quality control of the vegetable raw material is the analysis of the total ash content. Basically, these are the non-volatile residues coming from the mineral and organo-metallic self constituents (physiological ashes) or associated to foreign materials, especially sand and soil (non-physiological ashes) (Brazil, 1988; Costa, 2001). A content of $1.77 \%$ was identified for the leaf powder of $C$. pubescens, indicating that different values for this, perhaps due to adulteration.

The granulometry in the present study, it was observed that according to the Brazilian Pharmacopoeia IV (Brazil, 1988), leaves powder of $C$. pubescens is considered coarse because it remains $77 \%$ retained in the $710 \mu \mathrm{m}$ sieve.

The volatile oil of $C$. pubescens at the concentration used was inactive against Ae. aegypti larvae, according to the criteria described by Silvério et. al., (2020). Other species of the Myrtaceae family, however, have larvicidal activity as

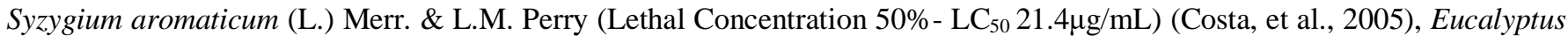
gunnii Hook. F. (LC ${ }_{50} 21.1 \mu \mathrm{g} / \mathrm{mL}$ ) (Lucia, et al., 2008), Pimenta racemosa (Mill.) J.W. Moore (LC 50 27 $\left.\mu \mathrm{g} / \mathrm{mL}\right)(\mathrm{Leyva}$, et al., 2009), Psidium guajava L. (LC $5024.7 \mu \mathrm{g} / \mathrm{mL}$ ) (Lima, et al., 2011b), Leptospermum scoparium J.R. Forst and G. Forst (LC 50 47.97ppm) (Muturi, et al., 2020), Callistemon citrinus (Curtis) Skeels LC $5017.3 \mu \mathrm{g} / \mathrm{mL}$ (An, et al., 2020), and Melaleuca leucadendra (L.) L (LC $\left.\mathrm{L}_{50} 1.4 \mu \mathrm{g} / \mathrm{mL}\right)$ (An, et al., 2020). Volatile oils are an interesting source of new insecticidal molecules, mainly because they are biodegradable and have low toxicity (Isman, 2020; Viana, et al., 2018).

\section{Conclusion}

It is concluded that the morpho-anatomical study of $C$. Pubescens is important in the correct taxonomic classification of the species. The phytochemical study, evaluation of volatile compounds content, total ash content, granulometry and intumescence provide quality control parameters for this plant raw material. The majority compounds found in the volatile oils were spatulenol, caryophyllene oxide, $\alpha$-macrocarpene, and z-caryophyllene. The presence of three clusters was observed, with cluster II corresponding to the reproductive period of the plant (flowering and fruiting) and clusters I and III to the vegetative period. No larvicidal activity of the volatile oil was observed against Ae. aegypti larvae. This work represents the first leaf anatomical description, chemical compounds, and seasonal variability of volatile oils from C. pubecens leaves collected in Goiás.

\section{Acknowledgments}

The authors gratefully acknowledge the financial support of the Coordenação de Aperfeiçoamento de Pessoal de Nível Superior - Brasil (CAPES), the Conselho Nacional de Desenvolvimento Científico e Tecnológico (CNPq), and the Fundação de Amparo à Pesquisa do Estado de Goiás (FAPEG). This study was financed in part by the CAPES, Finance Code 001.

\section{References}

Abe, S. Y., Mendes Silva, S., Possamai, J. C. \& Nakashima, T. (2014). Prospecção fitoquímica, teor de flavonoides totais e capacidade antioxidante de Campomanesia xanthocarpa Mart. ex O. Berg (Myrtaceae). Revista Eletrônica de Farmácia, 11 (2), 1-14.

Adams, R. P. (2007). Identification of essential oil components by Gas Chromatography/Mass Spectroscopy. (4th ed.), Carol Stream, IL: Allured Publ. Corp. Almeida, S. P., Proença, C. E. B., Sano, S. M. \& Ribeiro, J. F. (1998). Cerrado: espécies vegetais úteis. Planaltina: EMBRAPA-CPAC-DF.

Amaral, É. V. E. J., Reis, E. F., Ressel, K., \& Pinto F. N. (2016). Descrição morfológica de duas espécies de Campomanesia ruiz \& pavon (Myrtaceae). Revista Agrotecnologia, 7(1), 42-52. 
Amer, A. \& Mehlhorn, H. (2006). Larvicidal effects of various essential oils against Aedes, Anopheles, and Culex larvae (Diptera, Culicidae). Parasitology Research, 99 (4), 466-472. https://doi.org/10.1007/s00436-006-0182-3

An, N. T. G, Huong, L. T., Satyal, P., Tai, T. A., Dai, D. N., Hung, N. H., Ngoc, N. T. B. \& Setzer, W. N. (2020). Mosquito larvicidal activity, antimicrobial activity, and chemical compositions of essential oils from four species of Myrtaceae from Central Vietnam. Plants, 22, 9(4), 544. https://doi: $10.3390 /$ plants 9040544

Appezzato-da-Glória, B. \& Carmello-Guerreiro, S. M. (2009). Anatomia vegetal. Editora UFV.

APG IV (2016). Angiosperm Phylogeny Website. Version 14. Missouri Botanical Garden Retrieved from http://www.mobot.org/MOBOT/research/APweb/

Brasil (1988). Farmacopéia Brasileira. (4th ed.), Atheneu.

Brasil. Ministério da Saúde (2010). ANVISA. RDCNº10, de 9 de março de 2010. Dispõe sobre a notificação de drogas vegetais junto à ANVISA e dá outras providências. http://bvsms.saude.gov.br/bvs/saudelegis/anvisa/2010/res0010_09_03_2010.html.

Cardoso C. A. L. \& R-Poppi, N. (2009). Identification of the volatile compounds of flower oil of Campomanesia pubescens (Myrtaceae). Journal of Essential Oil Research, 21 (5), 433-434. https://doi.org/10.1080/10412905.2009.9700210

Cardoso, A. C. L., Salmazzo, G. R., Honda, N. K., Prates C. B., Vieira, M. C. \& Coelho, R. G. (2010). Antimicrobial activity of the extracts and fractions of hexanic fruits of Campomanesia Species (Myrtaceae). Journal of Medical Food, 13 (5), 1273-1276. https://doi.org/10.1089/jmf.2009.0047

Carr, D. J. \& Carr, S. M. G. (1970). Oil glands and ducts in Eucalyptus L’Hérit. II. Development and structure of oil glands in the embryo. Australian Journal of Botany, 18 (2), 191-212. https://doi.org/10.1071/BT9700191

Castro, M. M. \& Machado, S. R. (2003). Células e tecidos secretores. In: Appezzato-da-Glória B, Carmello-Guerreiro SM (eds). Anatomia Vegetal. Viçosa: Universidade Federal de Viçosa.

Chang, R., Morais, S. A. L., Nascimento, E. A., Cunha, L. C. S., Rocha, E.O., Aquino, F. J. T., Souza, M. G. M., Cunha W. R. \& Martins C. H. G. (2011). Essential oil composition and antioxidant and antimicrobial properties of Campomanesia pubescens O. Berg, native of brazilian Cerrado. Latin American Journal of Pharmacy, 30 (9): 1843-1848.

Consoli, R. A. G. B. \& Oliveira, R. L. (1994). Principais mosquitos de importância sanitária no Brasil. Editora Fiocruz.

Conti, E, Litt, A., Wilson, P. G., Graham, S. A., Briggs, B. G., Johnson, L. A. S. \& Sytsma, K. J. (1997). Interfamilial relationships in Myrtales: molecular phylogeny and patterns of morphological evolution. Systematic Botany, 22 (4), 629-647. https://doi.org/10.2307/2419432

Costa, A. F. (2001). Farmacognosia. Fundação Calouste Gulbenkian.

Costa, J. G. M., Rodrigues, F. F. G., Angélico, E. C., Silva, M. R., Mota, M. L., Santos, N. K. A., Cardoso, A. L. H. \& Lemos, T. L. G. (2005). Chemical biological study of the essential oils of Hyptis martiusii, Lippia sidoides and Syzigium aromaticum against larvae of Aedes aegypti and Culex quinquefasciatus. Brazilian Journal of Pharmacognosy, 15, 304-309. https://doi.org/10.1590/S0102-695X2005000400008

Cunha, A. P. (2005). Farmacognosia e fitoquímica. Fundação Caloustre Gulbenkian.

Dias, C. N. \& Moraes, D. F. C. (2014). Essential oils and their compounds as Aedes aegypti L. (Diptera: Culicidae) larvicides: review. Parasitology Research, 113, 565-592. https://doi.org/10.1007/s00436-013-3687-6.

Fahn, A. (1979). Secretory tissues in plants. Academic Press.

Fidalgo, A. O. \& Kleinert, A. M. P. (2009). Reproductive biology of six Brazilian Myrtaceae: is there a syndrome associated with buzz-pollination? New Zealand Journal of Botany, 47 (4), 355-365. https://doi.org/10.1080/0028825x.2009.9672712

Forzza, R. C. (2010). Catálogo de plantas e fungos do Brasil. Instituto de Pesquisas Jardim Botânico do Rio de Janeiro.

Gentry, A. H. (1992). Bignoniaceae Part II: Tribe Tecomeae. Flora Neotropica, 25 (2), 51-105.

Gobbo-Neto, L. \& Lopes, N. P. (2007). Plantas medicinais: fatores de influência no conteúdo de metabólitos secundários. Química Nova, 30 (2), 374-381. http://dx.doi.org/10.1590/S0100-40422007000200026

Gomes, S. M., Somavilla, N. S. D. N., Gomes-Bezerra, K. M., Miranda, S. C., Carvalho, P. S. \& Graciano-Ribeiro, D. (2009). Anatomia foliar de espécies de Myrtaceae: contribuições à taxonomia e filogenia. Acta Botanica Brasilica, 23, 224-238. https://doi.org/10.1590/S0102-33062009000100024

Guerrero, F. M. G., Zimmerman, L. R., Cardoso, E. V., Lima, C. A., Cardoso de Perdomo, R. T., Alva, R. \& Carollo, C. A. (2010). Investigação da toxicidade crônica das folhas de guavira (Campomanesia pubescens) em ratos machos. Revista Fitos, 5 (2), 64-72.

INMET (2020). Instituto Nacional de Meteorologia. Ministério da agricultura, pecuária e abastecimento. http://www.inmet.gov.br/portal/ (acessado em novembro de 2020).

Isman, M. B. (2020). Botanical insecticides in the twenty-first century-fulfilling their promise? Annual Review of Entomology, 65, 233-249. https://doi.org/10.1146/annurev-ento-011019-025010

Katsube, N., Iwashita, K., Tsushida, T., Yamaki, K. \& Kobori, M. (2003). Induction of apoptosis in cancer cells by bilberry (Vaccinium mirtillus) and the anthocyanins. Journal of Agricultural and Food Chemistry, 51, 68-75. https://doi.org/10.1021/jf025781x

Kraus, J. E. \& Arduin, M. (1997). Manual básico de métodos em morfologia vegetal. Ed. Universidade Rural. 
Kuster, V. C. \& Vale, F. H. A. (2016). Leaf histochemistry analysis of four medicinal species from Cerrado. Brazilian Journal of Pharmacognosy, 26, 673678. http://dx.doi.org/10.1016/j.bjp.2016.05.015

Landrum, L. R. (1986). Campomanesia, Pimenta, Blepharocalyx, Legrandia, Acca, Myrrhinium, and Luma (Myrtaceae). Flora Neotropica.

Landrum, L. R. \& Kawasaki, M. L. (1997). The genera of Myrtaceae in Brazil: an illustrated synoptic treatment and identification keys. Brittonia, 49, 508-536. https://doi.org/10.2307/2807742

Leyva, M., Marquetti, M. C., Tacoronte, J. E., Scull, R., Tiomno, O., Mesa, A. \& Montada, D. (2009). Actividad larvicida de aceites esenciales de plantas contra Aedes aegypti (L.) (Diptera: Culicidae). Revista Biomed, 20, 5-13.

Lima, D. F., Goldenberg, R. \& Sobral, M. (2011a). O gênero Campomanesia (Myrtaceae) no estado do Paraná, Rodriguésia, 62, 683-693. https://doi.org/10.1590/2175-7860201162313

Lima, M. A. A., Oliveira, F. F. M., Gomes, G. A. et al. (2011b). Evaluation of larvicidal activity of the essential oils of plants species from Brazil against Aedes aegypti (Diptera: Culicidae). African Journal of Biotechnology, 10, 11716-11720. https://doi.org/10.5897/AJB11.1102

Lorenzi, H., Souza, H. M., Torres, M. A. V. \& Bacher, L. B. (2003). Árvores exóticas do Brasil: madeireiras, ornamentais e aromaticas. Nova Odessa: Instituto Plantarium de Estudos da Flora.

Lucia, A., Licastro, S., Zerba, E. \& Masuh, H. (2008). Yield, chemical composition, and bioactivity of essential oils from 12 species of Eucalyptus on Aedes aegypti larvae. The Netherlands Entomological Society, 129, 107-114. https://doi.org/10.1111/j.1570-7458.2008.00757.x

Martius, C. F. P. (1897). Flora Brasiliensis, enumeratio plantarum in Brasilia hactenus detectarum: quas suis aliorumque botanicorum studiis descriptas et methodo naturali digestas partim icone illustratas. Flora Brasiliensis, 8(2), 383.

Metcalfe, C. R. \& Chalk, L. (1950). Anatomy of the dicotyledons. Oxford University Press.

Muturi, E. J., Selling, G. W., Doll, K. M., Hay, W. T. \& Ramirez, J. L. (2020). Leptospermum scoparium essential oil is a promising source of mosquito larvicide and its toxicity is enhanced by a biobased emulsifier. PLoS ONE, 15(2), 1-14. https://doi.org/10.1371/journal.pone.0229076

Ness, A. R. \& Powles, J. W. (1997). Fruit and vegetables, and cardiovascular disease: a review. International Journal of Epidemiology, 26 (1), 1-13. https://doi.org/10.1093/ije/26.1.1

Nucci, M. \& Alves-Junior, V. V. (2017). Biologia floral e sistema reprodutivo de Campomanesia adamantium (Cambess.) O. Berg- Myrtaceae em área de Cerrado no sul do Mato Grosso do Sul, Brasil. Interciencia, 42 (2), 127-131.

Oliveira, J. D., Alves, C. C. F., Miranda, M. L. D., Martins, C. H. G., Silva, T. S., Ambrosio M. A. L. V., Alves, J. M. \& Silva, J. P. (2016). Rendimento, composição química e atividades antimicrobiana e antioxidante do óleo essencial de folhas de Campomanesia adamantium submetidas a diferentes métodos de secagem. Revista Brasileira de Plantas Medicinais, 18, 502- 510. https://doi.org/10.1590/1983-084X/15_206

Oliveira, M. I. U., Rebouças, D. A., Leite, K. R. B., Oliveira, R. P.\& Funch, L. S. (2018). Can leaf morphology and anatomy contribute to species delimitation? A case in the Campomanesia xanthocarpa complex (Myrtaceae), Flora, 249, 111-123. https://doi.org/10.1016/j.flora.2018.10.004

Rodrigues, V. E. G. \& Carvalho, D. A.(2001). Plantas medicinais no domínio dos cerrados. UFLA.

Sangwan, N. S., Farooqi, A. H. A., Shabih, F. \& Sangwan, R. S. (2001). Regulation of essential oil production in plant. Plant Growth Regulation, 34, 3-21. https://doi.org/10.1023/A:1013386921596

Sano, S. M. \& Almeida, S. P. (1998). Cerrado: Ambiente e Flora. Mendonça RC et al. Flora vascular do Cerrado. Embrapa CPAC.

Schmid, R. (1972). A resolution of the Eugenia-Syzygium controversy (Myrtaceae). American Journal of Botany, 59, 423-436. https://doi.org/10.2307/2441553

Silva, E. P., Vilas Boas, E. V. B., Rodrigues, L. J. \& Siqueira, H. H. (2009). Physical, chemical and physiological characterization of gabiroba fruit. (Campomanesia pubescens) during its development. Ciência e Tecnologia de Alimentos, 29, 4, 803-809. http://dx.doi.org/10.1590/S010120612009000400016.

Silva, I. G., Silva, H. H. G. \& Lima, C. G. (2003). Ovipositional behavior of Aedes aegypti (Diptera, Culicidae) in different strata and biological cycle. Acta Biológica Paranaense, 32:1-8.

Silvério, M. R. S., Espindola, L. S., Lopes, N. P. \& Vieira, P. C. (2020). Plant natural products for the control of Aedes aegypti: The main vector of important arboviruses. Molecules, 25(15), 3484:1-42. https://doi.org/10.3390/molecules25153484

Sobral, M., Proença, C., Souza, M., Mazine, F. \& Lucas, E. (2015). Myrtaceae in lista de espécies da flora do Brasil. Jardim Botânico do Rio de Janeiro. Retrieved from http://floradobrasil.jbrj.gov.br/jabot/floradobrasil/FB171

Stoclet, J. C., Chataigneau, T., Ndiaye, M., Oak, M., Bedoui, J. E., Chataigneau, M. \& Schini-Kerth, V. B. (2004). Vascular protection by dietary polyphenols. European Journal of Pharmacology, 500, 299-313. https://doi.org/10.1016/j.ejphar.2004.07.034

Van Den Dool, H. \& Kratz, P. D. (1963). A generalization of the Retention Index system including linear temperature programmed gas - liquid partition chromatography. Journal of Chromatography, 11, 463-471. https://doi.org/10.1016/S0021-9673(01)80947-X

Viana, G. A., Sampaio, C. G. \& Martins, V. E. P. (2018). Produtos naturais de origem vegetal como ferramentas alternativas para o controle larvário de Aedes aegypti e Aedes albopictus. Journal of Health \& Biological Sciences, 6(4), 449-462. https://doi.org/10.12662/2317-3076jhbs.v6i4.2079. 
Research, Society and Development, v. 10, n.3, e35610313412, 2021

(CC BY 4.0) | ISSN 2525-3409 | DOI: http://dx.doi.org/10.33448/rsd-v10i3.13412

Wang, J. \& Mazza, G. (2002). Effects of anthocyanins and other phenolic compounds on the production of tumor necrosis factor alpha in LPS/IFN-gammaactivated RAW 264.7 macrophages. Journal of Agricultural and Food Chemistry, 50, 4183-4189. https://doi.org/10.1021/jf011613d

Ward, J. H. (1963). Hierarchical grouping to optimize an objective function. Journal of the American Statistical Association, 58, 236-244. https://doi.org/10.1080/01621459.1963.10500845

World Health Organization (2005). Guidelines for laboratory and field testing of mosquito larvicides. World Health Organization. Retrieved from http://apps.who.int/iris/bitstream/10665/69101/1/WHO_CDS_WHOPES_GCDPP_2005.13.pdf.

Zara, A. L. S. A., Santos, S. M., Fernandes-Oliveira, E. S, Carvalho, R. G. \& Coelho, G. E. (2016). Estratégias de controle do Aedes aegypti: uma revisão. Epidemiologia e Serviços de Saúde, 25(2), 391-404. https://doi.org/10.5123/S1679-4974201600020001 